Short Communication

\title{
Frequency of adult type-associated lactase persistence LCT-13910C/T genotypes in the Czech/Slav and Czech Roma/Gypsy populations
}

\author{
Jaroslav A. Hubácek ${ }^{1}$, Věra Adámková ${ }^{2}$, Lenka Šedová ${ }^{3}$, Věra Olišarová ${ }^{3}$, Václav Adámek $^{4}$ and Valérie \\ Tóthová ${ }^{3}$ \\ ${ }^{1}$ Centre for Experimental Medicine, Institute for Clinical and Experimental Medicine, Prague, Czech \\ Republic. \\ ${ }^{2}$ Department of Preventive Cardiology, Institute for Clinical and Experimental Medicine, Prague, Czech \\ Republic. \\ ${ }^{3}$ University of South Bohemia in České Budějovice, Faculty of Health and Social Studies, České Budějovice, \\ Czech Republic. \\ ${ }^{4}$ Czech Technical University of Prague, Faculty of Biotechnical Enginnering, Kladno, Czech Republic.
}

\begin{abstract}
Lactase non-persistence (leading to primary lactose intolerance) is a genetically dependent inability to digest lactose in adulthood. As part of the human adaptation to dairying, the human lactase LCT-13910C/T mutation (which propagates adult expression of lactase) developed, spread and participated in the adaptation to dairying. This variant is associated with lactase activity persistence, and its carriers are able to digest lactose. We compared the frequencies of lactase 13910C/T (rs4988235) genotypes in Czechs/Slavs $(\mathrm{N}=288)$ and Czech Gypsies/Roma $(\mathrm{N}=300)$, two ethnically different groups where this polymorphism has not yet been analysed. Allelic frequencies significantly differed between the populations $(p<0.0001)$. In Czechs/Slavs, the lactase persistence T allele was present in $76 \%$ of the individuals, which is in agreement with frequencies among geographically neighbouring populations. In the Czech Gypsy/Roma population, only $27 \%$ of the adults were carriers of at least one lactase persistence allele, similar to the Indian population. In agreement with this result, dairy product consumption was reported by $70.5 \%$ of Czechs/Slavs and $39.0 \%$ of the Czech Gypsy/Roma population. Both in the Czech Gypsy/Roma and in the Czech/Slavs populations, the presence of carriers of the lactase persistence allele was similar in subjects self-reporting the consumption of unfermented/fresh milk, in comparison to the others.
\end{abstract}

Keywords: Lactose, lactase persistence, polymorphism, Czech/Slav, Czech Gypsy/Roma.

Received: March 18, 2016; Accepted: July 27, 2016.

Lactase (lactase-phlorizin hydrolase-enzyme activities as described in EC 3.2.1.23 and EC 3.2.1.62) is an enzyme that cleaves disaccharide lactose (obtained in milk at about 4\%) into two simple sugars, glucose and galactose, both of which, unlike lactose, can be absorbed. Lactase non-persistence (OMIM acc No. 223100) is a time-dependent down-regulation of lactase enzyme activity in the small intestine. Lactase non-persistence leads to primary lactose intolerance and usually occurs between early childhood and puberty. It leads to physiological problems like flatulence, bloating and diarrhoea (Flatz and Rotthauwe, 1977).

Lactase is coded by the LCT gene (OMIM acc No. 603202). Lactase persistence is associated with the variant rs4988235 $(-13910 \mathrm{C} / \mathrm{T})$, which is located within the up-

Send correspondence to Jaroslav A. Hubacek. Centre for Experimental Medicine, Institute for Clinical and Experimental Medicine (IKEM-DEM), Videnska 1958/9, 14021 Prague 4, Czech Republic. E-mail: jahb@ikem.cz stream neighbouring gene, MCM6 (minichromosome maintenance complex component 6, OMIM acc No. 601806). The region within the MCM6 gene acts as a cis-element, which enhances differential transcriptional activation of the lactase promoter (Olds and Sibley, 2003). Altogether, there are five different point mutations within the MCM6 region, which seems to be responsible for the regulation of LCT gene expression (Gerbault et al., 2013).

Lactase persistence mutations are not evenly distributed across ethnic groups (Mattar et al., 2012; Gerbault et al., 2013), but they appear to reflect the ancient history of dairying among populations and of migration events. In Europeans, the $\mathrm{C} \rightarrow \mathrm{T}$ exchange at position $-13,910$ on the LCT gene (rs4988235) is the most common (Mattar et al., 2012) lactase persistence variant and has been confirmed to be functional in vivo (Fang et al., 2012).

Many (but not only) European individuals are carriers of the mutated allele and retain the ability to digest lactose through their entire lifespans. The reason for the advanta- 
geousness of this mutation is still debatable, but it is believed that it is an adaptation to settlements, the domestication of cattle, milk consumption (not only as a continuous source of energy, but also as an important non-seasonal source of calcium and vitamin D), and consumption of other dairy products led to the wide and rapid expansion of this mutation (Gerbault, 2013; Gerbault et al., 2013; Lachance and Tishkoff, 2013).

In our study, we analysed the prevalence of $L C T$ rs4988235 genotypes in Czechs/Slavs (non-Roma) and Czech Gypsies/Roma, given that within these ethnic groups no information has so far been reported on the distribution of the lactase persistence allele.

Six-hundred-and-one unrelated adults (at least 18 years old at the time of examination) were included in the study. Czech Gypsies/Roma (N=302) were recruited using snowball sampling (Hughes et al., 1995) and 298 Czechs/Slavs using quota sampling (for more details, see Adámková et al., 2015; Šedová et al., 2015; Tóthová et al., 2015), where gender (50:50\%) was used as a quota. Ethnicity was based on self-reported information. All subjects completed a one-day dietary record and the percentage of cases of milk and/or dairy product consumption/nonconsumption was calculated. Written informed consent was provided by all subjects enrolled in the study. The study was approved by the institution's ethics committee and conducted according to Good Clinical Practice guidelines.

DNA was isolated from DNA buccal swabs using the XTREME DNA kit (both Isohelix, Cell Project Ltd, UK) according to the manufacturer's instructions.

Rs4988235 genotypes were analysed using PCRRFLP (Mulcare et al., 2004). Briefly, oligonucleotides 5 '-gct ggc aat aca gat aag ata atg ga-3 and 5'-ctg ctt tgg ttg aag cga aga $\mathrm{t}-3$ were used for DNA amplification. All PCR chemicals were obtained from Fermentas International, Inc. (Burlington, ON, Canada) and PCR reactions were performed on an MJ Research DYAD Disciple PCR device. The PCR product (201 bp) was digested by $5 \mathrm{U}$ of the restriction enzyme Hinfl (Fermentas International Inc., Burlington, ON, Canada) overnight at $37{ }^{\circ} \mathrm{C}$. Restriction fragments were separated using $10 \%$ polyacrylamide gels based on the MADGE system (Day et al., 1996). PCR products were cut out as $177 \mathrm{bp}$ and $24 \mathrm{bp}$ restriction fragments where the lactose persistence allele T was present.

Deviations from the Hardy-Weinberg equilibrium were analysed using an online calculator (Court 20052008) and the differences in allele and genotype frequencies were compared using a chi-square test (Kirkman, 1996) in dominant, codominant and recessive models.

We successfully genotyped $288 \quad(96.0 \%)$ Czechs/Slavs (147 males and 141 females) and 300 (99.3\%) Czech Gypsies/Roma (151 males and 149 females) for the rs4988235 variant. In both groups, genotype distributions were within the Hardy-Weinberg equilibrium ( $\mathrm{p}=0.81$ for Czechs/Slavs and $\mathrm{p}=0.94$ for Czech
Gypsies/Roma). We observed no gender differences within ethnic groups in allele/genotype frequencies.

The prevalence of rs4988235 genotypes was significantly different $(p<0.0001$ for the codominant model of analysis) between the two ethnic groups under examination (Table 1). Significant differences observed also for dominant $\mathrm{p}<0.0001)$ and recessive $(\mathrm{p}<0.0001)$ models of analysis.

Within the Czech/Slav population, $23.6 \%$ of the individuals had the lactase $\mathrm{CC}$ non-persistence genotype. In contrast, in Czech Gypsy/Roma individuals, carriers of the lactase non-persistence CC genotype accounted for the vast majority of the population, specifically $73.3 \%$ of individuals. This finding is in agreement with the prevalence for milk/milk products consumption. All dairy consumption among Czechs/Slavs was reported at $70.5 \%$ but at only $37.3 \%$ among Czech Gypsies/Roma ( $<<0.0005)$.

Finally no differences between ethnic groups were observed, also in cases where unfermented/fresh milk consumers vs. others were analysed. No differences in genotype frequencies were detected in Czechs/Slavs $(p=0.43)$ or Czech Gypsies/Roma ( $p=0.14)$. In Czechs/Slavs, the frequency of the lactase persistence allele is almost identical to two geographically close populations, namely Poles (Kuokkanen et al., 2005; Madry et al., 2010) and Austrians (Tag et al., 2008).

It is noteworthy that by the use of computer simulation (Itan et al., 2009), the origin of the LCT gene mutation at position -13910 is pinpointed in Central Europe roughly $7,000-8,000$ years ago. This points to a huge (although probably still not fully understood) advantage of this mutation, since, especially in Northern Europe, around $80 \%$ of the population are carriers of at least one mutated allele.

In contrast, the frequency of this allele in Czech Gypsies/Roma is very similar to two Indian populations (Mattar et al., 2012). As mentioned elsewhere, the ancestry of European Roma/Gypsies is traceable to India (Mendizabal et al., 2011), and our results further confirm this geographical origin. Furthermore, our study highlights the non-assimilation of this ethnic group, which is in contrast with the observations of Hungarians, another central European population of Asian origin (Nagy et al., 2011). A

Table 1 - Frequency of LCT -13910C/T (rs4988235) genotypes in the Czech/Slav and Czech Gypsy/Roma populations.

\begin{tabular}{lcccc}
\hline & \multicolumn{2}{c}{ Caucasians } & \multicolumn{2}{c}{ Gypsies/Roma } \\
Rs4988235 & $\mathrm{N}$ & $\%$ & $\mathrm{~N}$ & $\%$ \\
\hline $\mathrm{CC}$ & 68 & 23.6 & 220 & 73.3 \\
$\mathrm{CT}$ & 146 & 50.7 & 74 & 24.7 \\
$\mathrm{TT}$ & 74 & 25.7 & 6 & 2.0 \\
$\mathrm{P}<0.0001$ & & & & \\
$\mathrm{C}$ & 282 & 49.0 & 514 & 85.7 \\
$\mathrm{~T}$ & 294 & 51.0 & 86 & 14.3 \\
$\mathrm{P}<0.0001$ & & & & \\
\hline
\end{tabular}


study of medieval samples (Krüttli et al., 2014) of German origin suggests that genetically dependent lactase persistence in Central Europe occurred as early as circa 1200 AD.

This is the first report to focus on the presence of the lactase persistence allele of the rs 4988235 (C-13910T, LCT gene) polymorphism within the Czech/Slav and Czech Roma/Gypsy populations. The differences we observed point to the origin of both ethnic groups and to the nonassimilation of Roma/Gypsies within the European region. Finally, in both groups, carriers of the lactase persistence allele occur similarly among consumers of unfermented milk and others.

\section{Acknowledgments}

The study was supported by project number LD14114 implemented under the financial support of the Ministry of Education, Youth and Sports within COST (Cooperation On Scientific and Technical Research), entitled "Obesity and overweight in the Romany minority in the Region of South Bohemia", and by the project supported by Ministry of Health Czech Republic - conceptual development of research organisation ("Institute for Clinical and Experimental Medicine - IKEM, IN 00023001”).

\section{References}

Adámkova V, Hubacek JA, Nováková D, Dolák F, Adámek V, Lánská V, Tóthová V and Šedová L (2015) Genetic and biochemical characteristics in the Roma minority in the South Bohemia Region. Neuro Endocrinol Lett 36(Suppl 2):29-34.

Day IN, Bolla M, Haddad L, O'dell S and Humphries SE (1996) Microtiter Array Diagonal Gel Electrophoresis (MADGE) for population scale genotype analyses. Methods Mol Med 5:269-281.

Fang L, Ahn JK, Wodziak D and Sibley E (2012) The human lactase persistence-associated SNP $-13910 * \mathrm{~T}$ enables in vivo functional persistence of lactase promoter reported transgene expression. Hum Genet 131:1153-1159.

Flatz G and Rotthauwe HW (1977) The human lactase polymorphism: Physiology and genetics of lactose absorption and malabsorption. Prog Med Genet 2:205-249.

Gerbault P (2013) The onset of lactase persistence in Europe. Hum Hered 76:154-161.

Gerbault P, Roffet-Salque M, Evershed RP and Thomas MG (2013) How long have adult humans been consuming milk? IUBMB Life 65:983-990.

Hughes AO, Fenton S, Hine CE, Pilgrim S and Tibbs N (1995) Strategies for sampling black and ethnic minority populations. J Publ Health Med 17:187-192.

Itan Y, Powel A, Beaumont MA, Burger J and Thomas MG (2009) The origins of lactase persistence in Europe. PLoS Comput Biol 5:e1000491.

Krüttli A, Bouwman A, Akgül G, Della Casa P, Rühli F and Warinner C (2014) Ancient DNA analysis reveals high frequency of European lactase persistence allele (T-13910) in medieval central europe. PLoS One 9:e86251.

Kuokkanen M, Butzow R, Rasinperä H, Medrek K, Nilbert M, Malander S, Lubinski J and Järvelä I (2005) Lactase persis- tence and ovarian carcinoma risk in Finland, Poland and Sweden. Int J Cancer 117:90-94.

Lachance J and Tishkoff SA (2013) Population genomics of human adaptation. Annu Rev Ecol Evol Syst 44:123-143.

Madry E, Lisowska A, Kwiecien J, Marciniak R, KorzonBurakowska A, Drzymala-Czyz S, Mojs E and Walkowiak J (2010) Adult-type hypolactasia and lactose malabsorption in Poland. Acta Biochim Pol 57:585-588.

Mattar R, de Campos Mazo DF and Carrilho FJ (2012) Lactose intolerance: Diagnosis, genetic, and clinical factors. Clin Exp Gastroenterol 5:113-121.

Mendizabal I, Valente C, Gusmão A, Alves C, Gomes V, Goios A, Parson W, Calafell F, Alvarez L, Amorim A, et al. (2011) Reconstructing the Indian origin and dispersal of the European Roma: A maternal genetic perspective. PLoS One 6:e15988.

Mulcare CA, Weale ME, Jones AL, Connell B, Zeitlyn D, Tarekegn A, Swallow DM, Bradman N and Thomas MG (2004) The allele of a single-nucleotide polymorphism $13.9 \mathrm{~kb}$ upstream of the lactase gene (LCT) (C-13.9 kbT) does not predict or cause the lactase-persistence phenotype in Africans. Am J Hum Genet 74:1102-1110.

Nagy D, Tömöry G, Csányi B, Bogácsi-Szabó E, Czibula Á, Priskin K, Bede O, Bartosiewicz L, Downes CS and Raskó I (2011) Comparison of lactase persistence polymorphism in ancient and present-day Hungarian populations. Am J Phys Anthropol 145:262-269.

Olds LC and Sibley E (2003) Lactase persistence DNA variant enhances lactase promoter activity in vitro: Functional role as a cis regulatory element. Hum Mol Genet 12:2333-2340.

Šedová L, Tóthová V, Olišarová V, Adámkova V, Bártlová S, Dolák F, Kajanová A, Mauritzová I, Nováková D and Prokešová R (2015) Evaluation of selected indicators of overweight and obesity of Roma minority in the region of South Bohemia. Neuro Endocrinol Lett 36(Suppl 2):35-42.

Tag CG, Oberkanins C, Kriegshäuser G, Ingram CJ, Swallow DM, Gressner AM, Ledochowski M and Weiskirchen R (2008) Evaluation of a novel reverse-hybridization StripAssay for typing DNA variants useful in diagnosis of adult-type hypolactasia. Clin Chim Acta 392:58-62.

Tóthová V, Bártlová S, Šedová L, Olišarová V, Prokešová R, Adámkova V, Mauritzová I, Treslova M, Chloubová I and Mikšová Z (2015) The importance of self-management in the prevention and treatment of excessive weight and obesity. Neuro Endocrinol Lett 36(Suppl 2):5-10.

\section{Internet Resources}

Court MH (2005-2008) Court-laboratory Hardy-Weinberg calculator; http://www.tufts.edu/ mcourt01/Documents/Court\%201ab\%20-\%20HW\%20calculator.xls (accessed February 2016).

Kirkman, TW (1996) Statistics to Use. http://www.physics.csbsju.edu/cgi-bin/stats/contingency_form.sh?nrow = 2\&ncolumn $=3$ (accessed February 2016).

\section{Associate Editor: Mara H. Hutz}

License information: This is an open-access article distributed under the terms of the Creative Commons Attribution License (type CC-BY), which permits unrestricted use, distribution and reproduction in any medium, provided the original article is properly cited. 